ZDZISŁAW J. KAPERA, KRAKÓW

\title{
KS. PROF. ALEKSY KLAWEK I POCZĄTKI BIBLII POZNAŃSKIEJ
}

W 2015 r. obchodzono w Polsce pięćdziesiątą rocznicę ukazania się pierwszego wydania Biblii Tysiąclecia opublikowanej przez Pallottinum. ${ }^{1}$ Biblia Tysiąclecia została zaakceptowana przez Kościół rzymskokatolicki w liturgii i nauczaniu religii. Pozostaje ona najbardziej popularną wersją Biblii w naszym kraju. Warto jednak zauważyć, że w tym samym roku przypadało czterdziestolecie ukończenia konkurencyjnego przekładu, tzw. (Nowej) Biblii Poznańskiej. Wydana w latach 1973-1975 w trzech woluminach została oceniona w 1999 r. przez biblistów jako najlepszy polski przekład Biblii z języków oryginalnych. ${ }^{2}$ We wstępie do pierwszego tomu tłumacze napisali: „Idea podjęcia niniejszego tłumaczenia Pisma św. z języków oryginalnych, wraz z komentarzem, wyszła od kapłana Archidiecezji Poznańskiej, ks. Prałata Aleksego Klawka, profesora UJ w Krakowie". ${ }^{3}$ W niniejszym artykule chciałbym przedstawić tło narodzin tego tłumaczenia i wyjaśnić, dlaczego nazwisko jej inicjatora, prawdopodobnie jednego z najlepszych polskich hebraistów XX w., nie pojawia się na stronie tytułowej tego wyjątkowego przekładu.

O historii polskich tradycji tłumaczeń Pisma Świętego ks. profesor Marian Wolniewicz tak pisał w 1974 r.: „Przegląd katolickich przekładów Pisma św. na język polski dokonywanych w ciągu XIX i XX wieku pokazuje, że wśród katolików istniały różne tendencje

1 Por. R. P i e t k i e w i c z, Biblia Polonorum. Historia Biblii w języku polskim, t. V: Biblia Tysiaclecia (1965-2015), Poznań 2015.

2 Por. W. Ch ro s to w s k i, Biblistyka katolicka w Polsce na progu XXI wieku, w: R. E. B row n, J. A. F it z m y e r, R. E. M u r p hy (red.), Katolicki komentarz biblijny, Warszawa 2001, s. 1772.

3 Pismo Święte Starego i Nowego Testamentu w przekładzie z języków oryginalnych ze wstępami i komentarzami, Stary Testament, t. 1, Poznań 1973, s. VII. 
tłumaczeniowe. Podczas gdy kościoły protestanckie wznawiały i modernizowały dawny przekład Biblii Gdańskiej dokonany z tekstów oryginalnych, a Żydzi tłumaczyli Stary Testament z Hebrajskiego, katolicy trzymali się kurczowo Biblii Wujka [z 1599 r.]. Ich postawa płynęła z mylnego przekonania, że przekład jezuicki otrzymał papieską aprobatę i posiada powagę autentycznego tłumaczenia Wulgaty. Modernizacja Biblii Wujka napotykała trudności. Równocześnie jednak, poczynając od lat dwudziestych ubiegłego stulecia, niepokoi biskupów (Korczyński, Dunin) i biblistów (Serwatowski, Nowodworski, Rzewuski, Jaczewski) myśl o nowym przekładzie. Przekład z języków oryginalnych uważano za nierealny (Nowodworski). Podjęto więc najpierw przekłady z Wulgaty (Symon, Klawek, Staff), a dopiero potem tłumaczenia z języków oryginalnych (Szczepański, Kruszyński, Michałowski, Hozakowski). Odwrót od Wulgaty nastąpił po Krakowskim Zjeździe Biblistów w 1937 r. Polscy egzegeci postanawiają przełożyć całą Biblię z języków oryginalnych". ${ }^{4}$ Ważną rolę w tym procesie odegrał ks. prof. Aleksy Klawek (1890-1969), luminarz Uniwersytetu im. Jana Kazimierza we Lwowie i Uniwersytetu Jagiellońskiego w Krakowie.

Ksiądz A. Klawek urodził się w Rogoźnie (Wielkopolska) w rodzinie nauczycielskiej i uczęszczał do gimnazjum klasycznego w rodzinnym mieście. Zdobył tam doskonałą znajomość języków starożytnych: łaciny, greki i hebrajskiego, a także niemieckiego, angielskiego i francuskiego. Przyjęty do seminarium, studiował w Poznaniu i Gnieźnie, gdzie został uczniem ks. Władysława Hozakowskiego, podówczas wysoko cenionego biblisty. ${ }^{5}$ Wyświęcony w 1913 r., już rok później został wysłany na studia teologiczne do Akademii w Monastyrze. W Westfalii napisał pracę doktorską na

4 M. Wo $1 \mathrm{n}$ i e w i c z, Od modernizacji Biblii Wujka do przekładów millenijnych, w: L. B i el e r zew s k i (red.), W stużbie Kościoła poznańskiego. Księga pamiątkowa na 70-lecie urodzin arcybiskupa metropolity dr. Antoniego Baraniaka, Poznań-Warszawa-Lublin 1974, s. 338.

5 Por. te n ż e, Studium Pisma Świętego w Arcybiskupim Seminarium Duchownym w Poznaniu w latach 1835-1939, Poznań-Warszawa-Lublin 1969, s. 40-53. 
bazie Nowego Testamentu o modlitwie do Jezusa w dobie wczesnego chrześcijaństwa. Dysertację przygotowaną pod kierunkiem Maxa Meinertza obronił w 1917 r. z oceną summa cum laude. Wydrukowana po kilku latach uzyskała dobre recenzje w liczących się europejskich teologicznych czasopismach. ${ }^{6}$ Kościelni przełożeni ks. Klawka byli zadowoleni zarówno z jego pastoralnej posługi pośród Polonii, jak też z jego badań naukowych. Pozwolili mu kontynuować studia najpierw na uniwersytecie w Monachium, gdzie zbierał materiały do przyszłej habilitacji, a następnie we Wrocławiu. W Monachium podczas wiosennego semestru 1917 r. brał udział w biblijno-egzegetycznym seminarium prof. O. Bardenhewera oraz w seminarium historii starożytnej prof. Wilckena, gdzie poszerzał swą wiedzę o okresie hellenistycznym. W czasie pobytu na uniwersytecie wrocławskim jesienią 1917 r. ks. Klawek nie tylko doskonalił egzegezę Nowego Testamentu pod kierunkiem prof. J. Sickenbergera, studiował język aramejski u prof. Praetoriusa, ale także często odwiedzał muzeum biblijne i słuchał wykładów z archeologii biblijnej prof. J. Nickla. W 1918 r., po krótkim okresie pracy parafialnej, ks. Klawek poprosił o zezwolenie na dwutygodniową wizytę w Berlinie. Tam zetknął się z wykładami sławnego A. Harnaka i zbierał materiały do pracy o imieniu Jezus. Po powrocie do Wielkopolski został nominowany profesorem $^{7}$ egzegezy Nowego Testamentu i wiosną 1919 r. rozpoczął wykłady w Arcybiskupim Seminarium w Poznaniu. W swoim programie studiów w latach 1919-1923 wprowadził metodę historyczno-krytyczną wykorzystując najświeższe osiągniecia biblistyki. Nadal się dokształcał. W 1922 r., przez pół roku przebywał w Paryżu,

$6 \quad$ A. K lawe k, Das Gebet zu Jesus. Seine Berichtigung und Übung nach dem Schriften des Neuen Testaments. Eine biblisch-theologische Studie, Münster 1921. Por. recenzje: B. B a r t m a n n w: Theologie und Glaube 14/1922, s. 178; Schultzen w: Theologische Literaturblatt 43/1922, s. 251-252; K. K a s t n e r w: Theologische Revue 22/1923, s. 194-195; J. L e b r e t o n w: Revue des Sciences Philosophiques et Théologiques 13/1924, s. 105-106; t e n ż e w: Biblische Zeitschrift 16/1924, s. 254-255. Jedyna polską recenzję opublikował J. Ur b a n w: Przegląd Powszechny 39/1922, s. 287-278.

7 Por. M. Wo 1 n i e w i c z, Studium Pisma Świętego, s. 59. 
uczęszczając na seminarium języka akadyjskiego i słuchając wykładów o. Marii Józefa Lagrange’a, czołowego francuskiego biblisty. ${ }^{8}$

To właśnie w tym okresie intensywnych studiów biblijnych w wielu centrach naukowych i równoległej pracy duszpasterskiej w środowisku polskim w Westfalii, na Pomorzu, pośród emigrantów w Paryżu i w samej Wielkopolsce ks. Klawek zetknął się z zapotrzebowaniem zarówno prostych, jak i wyedukowanym ludzi na nowy, łatwiejszy w czytaniu tekst polskiej Biblii. Osobiście bardzo wysoko cenił przekład ks. Wujka z 1599 r., który, mimo że pierwotnie był dokonany z języków oryginalnych, ostatecznie został ściśle adaptowany do tekstu Wulgaty. ${ }^{9}$ W 1920 r. jako pierwszy i chyba jedyny polski biblista napisał obszerną broszurę o św. Hieronimie, twórcy Wulgaty, w 1500-lecie jego śmierci. Jak stwierdził w niej, w czasach św. Hieronima wierni posługiwali się na co dzień Pismem Świętym. Apelował, aby wrócić do tej tradycji. ${ }^{10} \mathrm{~W}$ tym samym roku opublikował $w$ jednym $\mathrm{z}$ czasopism teologicznych rewolucyjny artykuł zatytułowany Więcej Pisma św., rzucając hasło: „Wysuńmy więc Pismo Święte na pierwsze miejsce". ${ }^{11}$ Krytykował w nim błędy w edukacji religijnej, sugerował wydawanie podręcznych tekstów Biblii, specjalnego brewiarza dla świeckich, modlitewników dla ludzi wykształconych, kazań i homilii do Biblii. Postulował wprowadzenie problematyki Biblii do edukacji szkolnej.

8 Por. R. Z i m n y, Całe życie z Biblią. Aleksy Klawek (1890-1969), Poznań 2004, s. 36-58; Z. J. K a p e r a, Curriculum vitae ks. Aleksego Klawka, Ruch Biblijny i Liturgiczny 33/1980, s. 221-223; M. W o 1 n i e w i c z, Studium Pisma Świętego, s. $58-61$.

9 Por. A. K l a w e k, Zarys dziejów teologii katolickiej w Polsce, Kraków 1948 s. 16: „A ks. Wujek nie tylko był dobrym stylistą, ale i znakomitym biblistą, był homo trilinguis, znawcą trzech języków: hebrajskiego, greckiego i łacińskiego, co było chlubą każdego humanisty, i dlatego jego przekład ma ścisłą wartość naukową. Żałować tylko należy, że tekst pisany ręką Wujka, nie poprawiony przez Komisję jezuicką, nigdzie się nie znalazł".

10 Te n ż e, Princeps exegetarum. Ku czci św. Hieronima (420-1920), Poznań-Warszawa 1920.

${ }^{11}$ Por. te n że, Więcej Pisma św., Wiadomości dla Duchowieństwa 7/1920, s. 367. 
Wydanie nowego tłumaczenia Biblii było dla niego oczywistą koniecznością. Ksiądz Wolniewicz ${ }^{12}$ był skłonny wierzyć, że naleganie przez ks. Klawka na nowe tłumaczenie było związane z wpływem ks. Hozakowskiego, jego pierwszego nauczyciela Biblii, uczonego, który próbował podjąć takie wyzwanie, a którego przekład pozostał w rękopisie i zaginąt. ${ }^{13}$ Osobiście widziałbym tu wynik osobistych doświadczeń ks. Klawka. Z jednej strony szkolił się u liderów europejskiej biblistyki, dostrzegał niezwykły postęp badań nad Pismem Świętym, zaś z drugiej strony przepracował kilka lat jako ksiądz pośród prostych ludzi. Wiedział, jak bardzo Biblia jest im potrzebna. Znał też zalecenie Exhortatio ad clerum papieża Piusa X, aby przybliżyć Biblię wiernym. ${ }^{14}$ Dlatego nie zawahał się wesprzeć moralnie ks. Stanisława Szczepańskiego, autora pierwszego nowoczesnego tłumaczenia Ewangelii i Dziejów Apostolskich ${ }^{15}$, stwierdzając w swej recenzji, że stanowi ono „piękną syntezę dzisiejszej egzegezy”. Według niego, ks. Szczepański „,skorzystał umiejętnie z nowszych badań biblijnych i oddał w swoim przekładzie myśli ewangeliczne tak, jak je przedstawiają dzisiejsi komentatorzy; a przy wyszukiwaniu odpowiednich polskich wyrazów postępował zupełnie samodzielnie, bo nie mamy w Polsce żadnych komentarzy lub prac biblijnych, na których by się mógł opierać". ${ }^{16}$ Uważał, że chociaż język jego tłumaczenia może być zarówno krytykowany, ${ }_{17}$ jak i chwalony, to jednak

12 M. W o $1 \mathrm{n}$ i e w i c z, Biblijna działalność ks. prof. Klawka w Wielkopolsce 1917-1923, Ruch Biblijny i Liturgiczny 23/1970, s. 272.

13 Zob. A. K l a w e k, Ś.p. Ks. Hozakowski, Collectanea Theologica 15/1934, s. 269.

14 Papież przypominał w niej życzenie św. Hieronima „Niech Pismo Święte zawsze będzie w waszych rękach".

15 W. S z c z e p ań s k i, Ewangelie i Dzieje Apostolskie, Kraków 1917.

16 A. K l a w e k, Krytycy przekładów Pisma św., Rzeczpospolita 2(1921) nr 167, s. 8 .

17 Prof. Ignacy C h r za n ow s k i z Uniwersytetu Jagiellońskiego, wybitny znawca literatury polskiej, niezwykle surowo ocenił przekład ks. Szczepańskiego; por. t e n ż e, Nowy przekład polski Pisma św., Kraków 1920. W rezultacie urażony ks. Szczepański nie ukończył planowanego przekładu całego Nowego Testamentu. Podobna historia wydarzyła się w związku z przekładem Starego Testamentu przez 
„na skutek dokładnego uwzględnienia sensu historycznego i związku gramatycznego w tekście oryginalnym, [jego translacja] pozostanie podstawą egzegetyczną wszelkich nowych przekładów". ${ }^{18} \mathrm{Ksiądz}$ Klawek na bieżąco śledził i oceniał polskie wysiłki przybliżenia Biblii rodakom i wyjaśniał brak efektów, wskazując na ograniczoną liczbę specjalistów i niedobory warsztatu naukowego. ${ }^{19}$ Wiele lat później napisał: „Jednakże myśl o konieczności nowego przekładu z tekstów oryginalnych powoli się przyjęła i miała być zrealizowana w późniejszym okresie". ${ }^{20}$ On sam nie miał dość czasu, aby wejść w tłumaczenie Biblii, jednak w 1924 r. wydrukował małą książeczkę do modlitwy opartą na tekstach Pisma Świętego. ${ }^{21}$

W okresie międzywojennym, ściślej między rokiem 1923 a 1939, ks. Klawek był profesorem, następnie dziekanem a wreszcie wicerektorem Uniwersytetu Jana Kazimierza we Lwowie. ${ }^{22}$ Mimo zaprezentowania we Lwowie habilitacji z zakresu Nowego Testamentu w 1921 r. $^{23}$, tamtejszy uniwersytet zaproponował mu w 1923 r. katedrę egzegezy Starego Testamentu. ${ }^{24}$ Ofertę przyjął, ale nie porzucił

abp. F. A. Symona. Jego przekład Pentateuchu z 1912 r. sprowokował spór polskich teologów, którzy zdecydowanie bronili przekładu ks. Wujka. Por. F. A. S y m o n, Pięcioksiag Mojżeszowy w nowym przekładzie polskim z tekstem łacińskiej Wulgaty, Warszawa 1912 i uwagi w: A. K 1 a w e k, Zarys dziejów teologii, s. 36; t e n ż e, Pogląd na prace teologów polskich w XX wieku, Ruch Biblijny i Liturgiczny 19/1966, s. 134.

18 Te n że, Więcej Pisma św., s. 369.

19 Te n że, O przekładach Pisma św., Rzeczpospolita 2(1921) nr 163, s. 4-5.

20 Te n ż e, Pogląd na prace teologów.

${ }_{21}$ Te n ż e, Słowa Żywota. Modlitewnik oparty na Piśmie św., Lwów 1924.

22 Idea wydziału teologicznego na UAM w Poznaniu nie została zrealizowana. Odnośnie do przejścia ks. Klawka do Lwowa, por. R. Z i m n y, Całe życie z Biblia, s. $69-70$.

23 Przedstawiona monografia była egzegetycznym studium narodzin Jezusa. Drukiem ukazała się tylko jej część: A. K l a w e k, Noc Betlejemska. Historia czy legenda? Obrona wiarygodności Łukasza 2, 1-20, Poznań 1921.

${ }^{24}$ Katedra Nowego Testamentu na UJK była już obsadzona przez ks. prof. Piotra Stacha; por. J. W o ł c z a ń s k i, Wydział Teologiczny Uniwersytetu Jana Kazimierza we Lwowie 1918-1939, Kraków 2002, s. 207. 
całkowicie pracy nad Nowym Testamentem, nawet rozszerzył zakres swych badań. Mając znakomite przygotowanie, mógł profesjonalnie reprezentować tę gałąź biblistyki na lwowskim uniwersytecie. Wyspecjalizował się w onomastyce biblijnej, ${ }^{25}$ badał Księgę Rodzaju, ale jego ulubionym polem badawczym stały się Psalmy. Jednak dość późno, bo dopiero w 1938 r., zaprezentował własny przekład Księgi Psalmów. ${ }^{26}$ Pragnąc uniknąć sporu ze zwierzchnictwem kościelnym, na stronie tytułowej wyraźnie zaznaczył, że chodzi o przekład z Wulgaty. ${ }^{27}$ Pozostawało to w zgodzie z ówczesną tendencją, jako że w latach 30. opublikowano pięć tomów nieukończonej „starej” Biblii Poznańskiej będącej poprawioną wersją starego tłumaczenia ks. Wujka, ciągle bazując na tekście Wulgaty. ${ }^{28}$ Faktycznie, jak ks. Klawek osobiście wzmiankował autorowi niniejszych słów w latach 60 ., jego tłumaczenie Psalmów zostało oparte na oryginalnym tekście hebrajskim, ${ }^{29}$ a jedynie zaadaptowane w sposób do przyjęcia przez władze kościelne. ${ }^{30}$ Nie jest dla mnie jasne, dlaczego ks. Klawek nie

25 Pozostała z tego okresu (ok. 1925 r.) dotąd nieopublikowana obszerna praca A. K 1 a w e k, Imię Jezus w świetle filologii biblijnej; por. Z. J. K a p e r a, Bibliografia prac księdza Aleksego Klawka (1890-1969), profesora U.J.K. i U.J., Ruch Biblijny i Liturgiczny 23/1970, s. 333, poz. 310.

26 Według Marka Pieli (powołującego się na wstęp ks. Klawka, zob. przyp. 27), ks. Klawek jako tłumacz nie starał się o dosłowność, ale zabiegał o zrozumiałość i wierne oddanie myśli oryginału. Zdawał sobie też sprawę z tego, że taki „wolny” przekład nie mógłby być przekładem oficjalnym dla władz Kościoła; por. M. P i e l a, Grzech dosłowności we współczesnych przekładach Starego Testamentu, Kraków 2003, s. 38.

27 A. K 1 a w e k, Psatterz. Nowy przekład tekstu Wulgaty, Lwów 1938.

28 Pismo Święte w tlumaczeniu Ks. J. Wujka opracowane przez XX. Prof. Dr. J. A r c hut ow ski e g o, Wł. Hozakow ski e go, J. K r y s z y ń skiego, W. Mi chalsk i e go, F. Rosłańc a, P. St a cha i Wł. Szczepańs k i e g o, t. I-V, Poznań 1926-1932.

29 Analiza wybranych elementów Psałterza ks. Klawka przez M. Pielę, moim zdaniem, może wskazywać na przekład bezpośrednio z hebrajskiego; zob. M. P i e l a, Grzech dosłowności, s. 55, 95, 96, 101, 110, 117, 118, 129, 130, 131, 221, 272, 273.

30 Ks. S. Smereka przedstawił inny pogląd. Wspominał: „Sam profesor swój wysiłek skoncentrował nad Psałterzem, uważając, że jest to księga najważniejsza z punktu widzenia liturgicznego. Niektóre psalmy przerabialiśmy na seminarium 
skorygował podtytułu swojego Psałterza, jako że w 1937 r., podczas spotkania biblistów z całej Polski, zdecydowano przełożyć całą Biblię $\mathrm{z}$ języków oryginalnych. Mogę jedynie sugerować, że korekty jego przekładu były wówczas tak zaawansowane, że nie było już możliwości usunięcia zmian wprowadzonych w celu zgodności z tekstem Wulgaty. Jednak to tłumaczenie potwierdziło wyjątkową pozycję ks. Klawka pośród naszych biblistów, co jest widoczne choćby w liczbie wydrukowanych recenzji i notek na temat tej edycji. ${ }^{31}$ Poczynając od tej publikacji, odważnie kontynuował swoje tłumaczenia Biblii. Trzeba bowiem przypomnieć mało znany fakt, że ks. Klawek doskonale zdawał sobie sprawę, że jakość jego języka literackiego z początków kariery naukowej była niedoskonała, jako że przez pierwsze trzy dekady swego życia mówił przeważnie po niemiecku i w tym

z uwzględnieniem tekstu hebrajskiego. Owocem pracy ks. Klawka był przekład Psalmów wydany w 1938 r. we Lwowie (Biblioteka Religijna). Miał to być wstęp do wydania przekładu całej Biblii w Drukarni św. Wojciecha. Wydając swój przekład Psałterza, polecił ks. Klawek sporządzić sobie jeden egzemplarz, w którym zadrukowana była tylko co druga kartka. Na kartkach czystych mógł robić sobie poprawki, doskonaląc swój przekład do przewidywanego drugiego wydania. Te swoje uzupełnienia i uwagi notował na czystych kartkach w czasie okupacji hitlerowskiej, gdy przebywał na wygnaniu w diecezji tarnowskiej. Uwag tych było dość dużo. Gdy spotkałem się z nim w marcu 1945 r., mówił że smutkiem, że jego praca nad przekładem z Wulgaty nie będzie już poza nim samym nikomu przydatna po ukazaniu się biblijnej encykliki Piusa XII zezwalającej na tłumaczenie Pisma św. z języków oryginalnych, «Musimy - mówił - rozpocząć pracę na nowo na podstawie tekstu hebrajskiego i greckiego»"; por. S. S m e r e k a, Biblia Poznańska. O nowym polskim przekładzie Pisma Świętego, Tygodnik Powszechny 28 (1974) nr 20, s. 7. Ponieważ oglądałem ten notatnik po śmierci ks. Klawka, to mogę potwierdzić, że istotnie pamiętam liczne notatki, ale tylko w języku hebrajskim, a więc możliwa jest i druga interpretacja, że tekst z 1938 był faktycznie przekładem z hebrajskiego. Końcowe zdania wspomnień ks. Smereki z pewnością dotyczą uwag ks. Klawka odnośnie do przekładu Biblii jako takiej, a nie pracy nad jego Psałterzem.

31 W latach 30. ukazało się wiele tłumaczeń Psalmów: ks. Edwarda Górskiego (1930), ks. Jana Szerudy (1934), ks. Józefa Kruszyńskiego (1936), ks. Mikołaja Biernackiego (1937), Leopolda Staffa (1938). Por. zestawienie w: S. G r z y b e k, H. C z e r w i eń, B. P a n a s i u k, Polska bibliografia biblijna za lata 1931-1965, Warszawa 1968, s. 175-177. 
języku pisał. W 1924 r., kiedy otrzymał propozycję przystąpienia do zespołu wydającego poprawioną Biblię ks. Wujka, z wielkim żalem zmuszony był odmówić. ${ }^{32}$

Po kolejnej publikacji Biblii Wujka w 1935 r., z nowymi zmianami renesansowego tekstu, ks. prof. Józef Archutowski z Uniwersytetu Jagiellońskiego opublikował negatywną ocenę tego thumaczenia. ${ }^{33}$ Ponieważ poprawki bazowały na wersjach Biblii Hebrajskiej i Greckiej, nowy tekst zgubił charakter tłumaczenia z łacińskiej Wulgaty. Piotr Stach, profesor Uniwersytetu Jana Kazimierza we Lwowie, komentując ten zarzut, zaproponował, aby wersja Wujka pozostała nadal w liturgii, podczas gdy nowe tłumaczenie, koniecznie z języków oryginalnych, powinno być przygotowane do użytku prywatnego. Wskazał na ks. prof. Archutowskiego, wybitnego znawcę Starego Testamentu, jako edytora takiego wydania. Sugerował, aby to on sam zwrócił się do polskich biblistów o współpracę. ${ }^{34} \mathrm{~W}$ rezultacie

32 Ks. Władysław Smereka, uczeń ks. Klawka, po latach wspominał: „Gdy Księgarnia św. Wojciecha zwróciła się do ks. Klawka, będącego wówczas prof. UJK we Lwowie, z prośbą o współpracę, odmówił, tłumacząc się, że wykształcony na uniwersytetach niemieckich nie odważyłby się poprawiać pięknego tekstu Wujkowego; niemniej podkreślał, że bibliści polscy winni postarać się o nowy przekład i sam nad tym zaczął poważnie myśleć”; W. S m e r e k a, Biblia Poznańska. Gdy w latach 60 . ks. Klawka wizytował prof. Horst Klengel, wybitny znawca starożytnego Wschodu, po długiej z nim rozmowie stwierdził, na spotkaniu ze mną: „Co za wspaniała niemczyzna! Tyle, że pan profesor mówi językiem sprzed pół wieku”. Ks. Klawek zdawał sobie z tego sprawę i, jak mi kiedyś tłumaczył, dlatego po wojnie nie pisze już w tym języku. Po śmierci ks. Klawka, ks. prof. Michał Peter, też jego uczeń, napisał: „,Dopiero wytrwała lektura i żywe kontakty z polonistami sprawiły, że po kilku latach pracy godnej Demostenesa ks. Klawek tak świetnie władał już językiem polskim, iż jego artykuły przyciągały i samą treścią, i pięknem formy literackiej. Wyrazem tego było w roku 1938 wydanie «Psałterza» w nowym przekładzie z Wulgaty; krytyka przyjęła go nader życzliwie"; M. P e t e r, Człowiek uniwersytetu (Aleksy Klawek 1890-1969), w: F. L e n o r t (red.), Byli wśród nas, Poznań 1973, s. 354.

33 Por. J. A r chutow s k i, Uwagi o nowych wydaniach Pisma Świętego, Kraków 1936.

34 P. S t a c h, O potrzebie nowego polskiego przekładu Pisma św., Collectanea Theologica 17/1936, s. 432-461. 
ks. Archutowski zwołał pierwszy Zjazd Biblistów Polskich i 31 marca 1937 r. przybyło do Krakowa trzydziestu czterech profesorów z siedemnastu seminariów i uniwersytetów. Zebrani wysłali telegram do papieża Piusa XI, informując go, że pragną dyskutować o problemie nowego przekładu Biblii. W odpowiedzi otrzymali peramenter, błogosławieństwo z Watykanu.

W trakcie zjazdu ks. prof. W. Prokulski zaskoczył biblistów wykładem, w którym obalił kilka mitów krążących od XIX w. w polskim Kościele. I tak, przekład ks. Wujka wydany w 1599 r. był po jego śmierci „, znacznym stopniu przerobiony i zmieniony” przez komisję jezuicką. Nie otrzymał on aprobaty stolicy apostolskiej. Przeżegnanie, udzielone przez papieża Grzegorza XIII, ,nie było aprobatą, a tylko przyzwoleniem na wydanie polskiego przekładu". Co najistotniejsze, ks. Prokulski wykazał, że Synod piotrkowski z 1607 r. „nie ogłosił przekładu X. Wujka za tekst obowiązujący w Kościele polskim”. Podsumowując słowami ks. Archutowskiego, „straszak XIX w., jakoby tekst Wujka był «autentyczny» i nie wolno w nim żadnych zmian dokonywać, został usunięty. Skończył się ponadto mit, że nie wolno używać innego (katolickiego) przekładu, jak tylko ks. Wujka". ${ }^{35}$

Z kolei w referacie o. Smorońskiego, który przeanalizował dekret Soboru Trydenckiego o autentyczności Wulgaty, zostało wyjaśnione obecnym, że ,dekret ten ma charakter dyscyplinarny, a nie dogmatyczny”. Określając to, „nie twierdził, że tekst jej jest całkowicie zgodny z tekstami oryginalnymi, przyznawał jej zgodność z nimi w rzeczach zasadniczych, bezbłędność w rzeczach wiary i obyczajów". ${ }^{36} \mathrm{~W}$ efekcie oba referaty pozwoliły na pozbycie się przez polskich biblistów pewnych uprzedzeń i przeprowadzenie rzeczowej dyskusji odnośnie do charakterystyki i metodologii planowanego przekładu Biblii na język polski oraz w jaki komentarz powinno ono być zaopatrzone. Zdecydowano, że przyszłe tłumaczenia muszą być przygotowane zarówno do naukowego, jak i prywatnego użytku.

35 Cyt. za: J. A r c hu to w s k i, I Zjazd Biblistów Polskich, Przegląd Biblijny 1/1937, s. 101-102.

36 Cyt. za: tamże, s. 102. 
Komentatorzy poszczególnych ksiąg muszą brać pod uwagę potrzeby kleru, jak i świeckich, zaś w przypadku miejsc niejasnych i spornych tłumacze powinni uwzględniać aktualne wyniki badań biblijnych. Tłumaczom rekomendowano unikanie hebraizmów i języka archaicznego. Jako przykład i wzór sugerowano tzw. Bonner Bibel.

$\mathrm{Na}$ zakończenie konferencji został wybrany specjalny komitet nadzorujący tłumaczenie oraz dwa podkomitety dla Starego i Nowego Testamentu. Na jednego z członków pięcioosobowej grupy do spraw Starego Testamentu powołano ks. prof. Aleksego Klawka. Celem podkomitetów było zapewnienie dokładności i jednolitości przekładu poszczególnych ksiąg biblijnych. Podkomitety zobligowano także do przygotowania uwag praktycznych dla tłumaczy i udzielenia im szczegółowych instrukcji o sposobie przekładu. ${ }^{37}$

Druga wojna światowa nie tylko przerwała prace nad nowym przekładem Biblii, ale znacząco wpłynęła na życie ks. Klawka. Przetrwał co prawda najpierw rosyjską (we Lwowie), a następnie niemiecką okupację na terenie Generalnego Gubernatorstwa, przebywając daleko od centrum naukowego w małych wioskach Małopolski i biorąc udział w podziemnym nauczaniu młodzieży. Po wojnie nie wrócił ani do Lwowa (wcielonego do USRR), ani do rodzinnej Wielkopolski. Przyjął katedrę Starego Testamentu na ponownie otwartym w 1945 r. Wydziale Teologicznym Uniwersytetu Jagiellońskiego. ${ }^{38}$ Zanim komuniści zdecydowali się zamknąć Wydział Teologiczny w 1953 r., ks. dziekanowi Klawkowi udało się promować około czterdziestu doktorów i szesnastu profesorów. Warto przypomnieć, że jednym z ostatnich habilitantów był ks. Karol Wojtyła, późniejszy papież Jan Paweł II. ${ }^{39}$ Niektórzy z jego doktorantów specjalizujący się w zakresie Starego Testamentu przygotowali pod kierunkiem ks. Klawka swoje

37 Tamże, s. 106.

38 Por. J. S z c z e pa n i a k, Aleksy Klawek (1890-1969), w: S. P i e c h (red.), Złota Księga Papieskiej Akademii Teologicznej, Kraków 2000, s. 493.

39 Ks. Karol Wojtyła znał ks. Klawka od 1946 r. - 1 lipca 1946 zdał u niego celująco egzamin ze Starego Testamentu, uzyskując najwyższą notę, eminenter; por. R. Z i m n y, Całe życie z Biblia, s. 151; A. B o n i e c k i (red.), Kalendarium życia Karola Wojtyły, Kraków 1983, s. 96. 
dysertacje w taki sposób, że pozwoliło im to później opublikować ich tłumaczenia i komentarze naukowe do poszczególnych ksiąg biblijnych. Przed zamknięciem Wydziału powstało co najmniej sześć takich prac. ${ }^{40}$ Na przełomie lat 40. i 50. XX w. ks. Klawek nie tylko nadzorował prace i tłumaczenia swych uczniów, ale w założonym przez siebie naukowo-popularnym dwumiesięczniku „Ruch Biblijny i Liturgiczny"41 zaczął publikować własne przekłady fragmentów zarówno Starego, jak i Nowego Testamentu, w sumie aż z trzydziestu sześciu ksiąg Biblii. Między innymi przełożył około trzydziestu psalmów i obszerne fragmenty Izajasza. ${ }^{42}$ Można by przyjąć, że w ten sposób starał się wypełnić swe moralne zobowiązania jako członek komitetu powołanego w $1937 \mathrm{r}$.

W latach powojennych ks. Klawek starał się odnowić Polskie Towarzystwo Teologiczne i zorganizował dwa ogólnopolskie kongresy w 1946 i 1948 r. W 1949 r. uczcił specjalną sesją jubileuszową w Krakowie 350-lecie ukazania się thumaczenia Biblii ks. Wujka. ${ }^{43}$ Jako że w Krakowie były zlokalizowane liczne seminaria dla osób duchownych, ks. Klawek doprowadził w 1947 r. do spotkania ich rektorów w sprawie czytania i studiowania Pisma Świętego przez alumnów. ${ }^{44}$ W tym czasie problem nowego tłumaczenia Pisma Świętego stał się ponownie palącą kwestią. Opublikowane tuż po wojnie przekłady Nowego Testamentu przez ks. Feliksa Gryglewicza (tłumaczenie

40 Por. M. P e t e r, Człowiek uniwersytetu, s. 354. M. Wolniewicz odnotował także, że kilka doktoratów z zakresu Nowego Testamentu, zawierających przekłady, zostało przygotowane pod kierunkiem ks. Klawka; por. M. W o $1 \mathrm{n}$ i e w i c z, Powojenne przekłady Pisma Świętego na język polski, w: J. Ł a c h, M. W o $1 \mathrm{n}$ i e w i c z (red.), Współczesna biblistyka polska 1945-1970, Warszawa 1972, s. 251.

${ }^{41}$ Ks. Klawek przez wiele lat przed II wojną światową, od 1925 r., był współredaktorem, a od 1927 r. redaktorem samodzielnym kwartalnika „Przegląd Teologiczny”, do którego wprowadził artykuły obcojęzyczne, a nawet zmienił jego tytuł na „Collectanea Theologica”.

${ }^{42}$ Wykaz tłumaczeń w: Z. J. K a p e r a, Bibliografia prac księdza Aleksego Klawka, s. 300 (indeks).

43 Te n ż e, Curriculum vitae ks. Aleksego Klawka, s. 223-224.

44 Por. S. S m e r e k a, Ruch Biblijny w Polsce, Ruch Biblijny i Liturgiczny 1/1948, s. 100. 
z greki) oraz ks. Eugeniusza Dąbrowskiego (tłumaczenie z Wulgaty) były żywo dyskutowane, podobnie zresztą jak polskie tłumaczenie Księgi Psalmów przygotowane na bazie łacińskiej wersji przekładu tej księgi z oryginału hebrajskiego przez profesorów Papieskiego Instytutu Biblijnego w Rzymie. Prawdopodobnie zarówno to nowe thumaczenie Psałterza z 1946 r., ${ }^{45}$ jak i uprzednio dyrektywa Piusa XII z 1943 r. odnośnie do studiów biblijnych skłoniły ks. Klawka do regularnego druku własnych przekładów na łamach „Ruchu Biblijnego i Liturgicznego". Osobiście jednak uważał w tym okresie, że było za wcześnie, by myśleć o podjęciu się przekładu całego Pisma Świętego. Utalentowani uczeni, którzy mogliby dokonać tego zadania, zmarli w czasie wojny lub zostali zamordowani przez niemieckiego okupanta. Wojnę przeżyło naprawdę niewielu biblistów. ${ }^{46}$ Edukując więc swoich uczniów, ks. Klawek przygotowywał także przyszłych tłumaczy. W tym czasie Kraków, obok Katolickiego Uniwersytetu Lubelskiego, był najważniejszym centrum naukowych badań biblijnych. Gdy rząd komunistyczny zamknął Wydział Teologiczny na UJ w 1953 r., sytuacja uległa pogorszeniu.

W trakcie odwilży w $1956 \mathrm{r}$. miało miejsce ważne wydarzenie. W Lublinie zebrało się na konferencji Pismo Święte $w$ duszpasterstwie współczesnym około sześciuset księży z całej Polski. Co budzi zdziwienie, w czasie spotkania nie dyskutowano problemu przekładu Pisma Świętego i to mimo faktu, że podczas sesji wygłoszono kilka wykładów na temat bardzo wtedy w Europie popularnego i już zaakceptowanego w Polsce tzw. Ruchu Biblijnego. Obecni na konferencji apelowali o przygotowanie obszernego komentarza do całej Biblii, o tanie wydanie Nowego Testamentu, o podręcznik Biblii dla

45 Stało się ono tak popularne w Polsce, że ks. Klawek przygotował, wespół ze swymi studentami, specjalny słownik i wstęp do Psałterza; por. A. K l a w e k, Słownik do Nowego Psałterza, Stalinogród 1955.

${ }^{46}$ Ks. W. Smereka doliczył się dziesięciu znakomitych biblistów, którzy nie przeżyli II wojny światowej. Właśnie ta grupa pośród teologów poniosła największe straty osobowe; zob. W. S m e r e k a, Ruch Biblijny, s. 97. 
szkół, ale nie o całościowy przekład Pisma Świętego. ${ }^{47}$ Choć trzeba przyznać, że postulat co rychlejszego wydania Starego Testamentu padał $w$ dyskusji. ${ }^{48}$

Przywilej inicjatywy tzw. Biblii Tynieckiej, przemianowanej ostatecznie na Biblię Tysiąclecia, przypadł nieoczekiwanie nie któremuś z liderów polskiej biblistyki, ale regularnym benedyktyńskim mnichom z Tyńca koło Krakowa. ${ }^{49}$ Po otrzymaniu w 1958 r. kieszonkowego wydania Biblii Jerozolimskiej, dwoje zakonników, o. Dominik Michałowski i o. Karol Meissner, zaczęło myśleć o przygotowaniu podobnego tłumaczenia dla Polaków. Nalegali na jednego z braci, o. Augustyna (Bogdana) Jankowskiego, wybitnego znawcę Nowego Testamentu, na podjęcie inicjatywy przygotowania zbiorowego tłumaczenia na język polski całej Biblii z języków oryginalnych. W rezultacie presji współbraci i zwierzchników o. Jankowski zdecydował się podjąć inicjatywę. Na spotkaniu biblistów w Lublinie w 1958 r. wygłosił referat pt. Rozwój nauk biblijnych a potrzeby duszpasterstwa polskiego. Stwierdził w nim m.in.: „Palącą sprawą zatem jest ukazanie się pełnego przekładu na język polski Pisma św. z języków oryginalnych. Na Zachodzie w każdym kraju kilka takich tłumaczeń ze sobą współzawodniczy, a z wyników podobnej rywalizacji korzysta najpełniej odbiorca. My w Polsce dotąd nie zdobyliśmy się ani na jedno takie tłumaczenie całego Pisma św." ${ }^{50}$ Po latach o. Jankowski wspominał, że w czasie dyskusji, „,wśród wniosków zgłosiłem projekt podjęcia się zbiorowym wysiłkiem małego wydania Pisma św. w przekładzie z języków oryginalnych. Sugerowałem wówczas profesorom KUL objęcie redakcji tej pracy, obiecując w imieniu Tyńca współpracę. Sugestia moja co do redakcji nie została podjęta". ${ }^{51}$

47 Zob. E. D ą b row s k i (red.), Pismo Święte w duszpasterstwie współczesnym, Lublin 1958.

48 Por. J. S t ę p i eń, Przebieg zjazdu i jego znaczenie, w: tamże, s. 278.

49 Por. R. P i e t k i e w i c z, Biblia Polonorum, t. V, s. 108-112.

50 A. J a n k ow s k i, Rozwój nauk biblijnych a potrzeby duszpasterstwa polskiego, Ruch Biblijny i Liturgiczny 12/1959, s. 166-167.

51 Te n ż e, Jak powstała „Biblia Tysiaclecia”, Biuletyn Ekumeniczny 16/1972, s. $39-40$. 
Ówczesne sprawozdanie z tej konferencji, przygotowane przez ks. dr. Witolda Tylocha, ucznia ks. prof. Stanisława Łacha z KUL, zdaje się potwierdzać przekaz o. Jankowskiego. Brak w nim nawet wzmianki o inicjatywie o. Jankowskiego, zarówno w streszczeniu jego referatu, jak też w podsumowaniu ogólnej dyskusji. ${ }^{52}$ Ojciec Jankowski był jednak konsekwentny. W 1959 r. odbyło się kolejne zgromadzenie biblistów polskich, tym razem w Krakowie. W sprawozdaniu z niego znajdujemy bezcenną ${ }^{53}$ informację, że w trakcie dyskusji „o. Augustyn Jankowski z Tyńca mówił o wydaniu całego Pisma św. w przekładzie z języków oryginalnych na wzór francuskiej Bible de la poche. $\mathrm{W}$ wydawnictwie tym bierze udział 41 profesorów, a wydania podjęło się wydawnictwo Pallottinum". ${ }^{54}$ Zdziwienie musi budzić fakt, że ta informacja, o tak ważnym projekcie, nie była dyskutowana podczas konferencji, a jedynie podana w dyskusji przez samego o. Jankowskiego. ${ }^{55}$

Chcąc wyjaśnić ówczesną sytuację o. Jankowskiego, konieczne jest przypomnienie, że w okresie powojennym zarówno Lublin, jak i Kraków były ośrodkami konkurencyjnymi w badaniach biblijnych. Przed wojną to Lwów i Kraków górowały poziomem badań nad resztą kraju. Po zmianie granic w 1945 r. wielu profesorów lwowskich przeniosło się do Krakowa. Tutaj działalność ks. Klawka i jego kolegów, utworzenie nowego czasopisma biblijnego, rozwijanie Ruchu Biblijnego, organizacja kongresów teologicznych tworzyły solidną bazę rozwoju studiów biblijnych, która nieoczekiwanie została przerwana zamknięciem Wydziału Teologicznego UJ w 1954 r. Nowe

52 Por. W. Tyl o c h, Sprawozdanie z obrad sekcji biblijnej, Ruch Biblijny i Liturgiczny 11/1958, s. 448-456.

53 Używam tego szumnego określenia, gdyż ustalenie ścisłej chronologii powstania Biblii Tysiąclecia nadal budzi wiele wątpliwości; por. R. P i e t k i e w i c z, Biblia Polonorum, t. V, s. 112-113.

54 F. Jó ź w i a k, Seminarium naukowe biblistów polskich, Roczniki Teologiczno-Kanoniczne 7(1960) nr 3, s. 138.

55 Profesorowie KUL skupieni byli na swoim projekcie naukowych komentarzy do ksiąg Starego Testamentu i, jak się wydaje, nie docenili, czy raczej nie wierzyli w możliwość, realizacji inicjatywy o. Jankowskiego. 
inicjatywy zaczęły się więc pojawiać w środowisku Katolickiego Uniwersytetu Lubelskiego. Ksiądz prof. Stanisław Łach zainicjował serię naukowych komentarzy do Starego Testamentu, ${ }^{56}$ do pisania których zamierzał dołączyć ks. Klawek.$^{57}$ Ksiądz prof. Eugeniusz Dąbrowski zapoczątkował natomiast udaną serię komentarzy do Nowego Testamentu, ${ }^{58}$ a także zebrał zespół pracujący nad dwutomową encyklopedią biblijną. ${ }^{59}$

Ojciec Jankowski zdawał sobie sprawę z ambicji i animozji ośrodków krakowskiego i lubelskiego, a jego projekt miał ogromną wagę. Zaś jego pozycja była dość nietypowa. Posiadał co prawda habilitację, uzyskaną w 1952 r. na Wydziale Teologicznym Uniwersytetu Warszawskiego, ale w końcu lat 50. nie był regularnym nauczycielem akademickim, lecz tylko zakonnikiem z Tyńca. ${ }^{60}$ Mimo tego był jednak wysoko ceniony. W 1958 r. opublikował tom studiów nad Nowym Testamentem, ${ }^{61}$ a rok później naukowy komentarz do Apokalipsy. ${ }^{62}$ Mógł więc spodziewać się życzliwej akceptacji projektu tłumaczenia Biblii. Oczekiwał licznych zgłoszeń biblistów do

56 Seria do dziś nieukończona.

57 Według informacji ks. S. Łacha, ks. Klawek zamierzał dostarczyć komentarz do Księgi Psalmów w 1961 r.; por. F. Jóź w i a k, Seminarium naukowe. Nie wydaje mi się jednak, aby ks. Klawek podjął to zobowiązanie. W tym okresie poważnie i na dłużej zachorował (pod koniec lat 50.), zaś od 1960 r. intensywnie powrócił do pasjonującej go onomastyki biblijnej, a potem głęboko zaangażował się w problematykę soborową; por. R. Z i m n y, Całe życie z Biblia, s. 168-176. Można to zauważyć, przeglądając listę jego publikacji; por. Z. J. K a p e r a, Bibliografia prac księdza Aleksego Klawka, s. 328.

58 Serię komentarzy do Nowego Testamentu wydano w latach 1958-1979.

59 E. D ą b row s k i (red.), Podręczna encyklopedia biblijna, t. 1-2, Poznań-Warszawa-Lublin 1960.

${ }^{60}$ Wydział Teologiczny Uniwersytetu Warszawskiego został zamknięty wkrótce po jego habilitacji, a on sam został powołany na wykładowcę Papieskiej Akademii Teologicznej w Krakowie dopiero w 1963 r.; por. W. C h r o s t o w s k i, O. Prof. Dr hab. Augustyn Jankowski (14 IX 1916 - 6 XI 2005), Zeszyty Naukowe Stowarzyszenia Biblistów Polskich 3/2006, s. 342, 344.

${ }_{61}$ A. J a n k o w s k i, Z rozważań nad Nowym Przymierzem, Poznań 1958.

${ }_{62}$ Te n ż e, Apokalipsa św. Jana, Pismo Święte Nowego Testamentu 12, Poznań 1959. 
tłumaczenia poszczególnych ksiąg i chętnych do współpracy przy ich redakcji. Osobiście był zniechęcony milczeniem zespołu kulowskiego i w związku z tym sam odważnie podjął konkurencyjne dla Lublina przedsięwzięcie, angażując ponad czterdziestu biblistów z całej Polski.

Z korespondencji o. Jankowskiego z Wydawnictwem Pallottinum wynika, że liczył na udział ks. Klawka w swym projekcie. W piątym tomie historii Biblii w języku polskim ks. Rajmund Pietkiewicz przytacza pewne fakty odnośnie do ks. Klawka i jego stosunku do projektu „Biblii Tynieckiej”. Jak się wydaje, otrzymał on list z oficjalnym zaproszeniem do współpracy bardzo późno, bo 19 grudnia 1959 r., choć mniej więcej równocześnie $\mathrm{z}$ innymi tłumaczami. ${ }^{63} \mathrm{Na}$ grudniowej liście tłumaczy jego nazwisko występuje jako potencjalnego tłumacza Księgi Lamentacji. Jednakże w listopadzie 1960 r. o. Jankowski informuje Pallottinum, że ta księga została ostatecznie przyznana ks. prof. Władysławowi Borowskiemu. ${ }^{64}$ Jak wspomina o. Jankowski: „Z odmową współpracy spotkałem się zaledwie w pięciu przypadkach, po większej części zaproszeni okazywali wielką chęć współpracy, przy czym krakowskie środowisko okazało najwięcej pomocy". ${ }^{65}$

Dlaczego ks. Klawek odmówił współpracy? Według ks. Pietkiewicza, „ostatnie pismo wysłane przez wydawnictwo do Aleksego Klawka, dotyczące tłumaczenia Lamentacji, nosi datę 5 maja 1960 r., nie ma jednak w przebadanych archiwach żadnej odpowiedzi od adresata, który definitywnie odmówił udziału w pracach nad Biblią Tysiąclecia wiosną 1960 r. Ojciec Jankowski uważał, że odmowa ks. Klawka mogła być podyktowana względami ambicjonalnymi”, ${ }^{66}$ W przypisie ks. Pietkiewicz dodaje, że ,umowę do podpisania A. Klawek otrzymał jako jeden z pierwszych pod koniec marca lub na początku kwietnia 1960 r.”. ${ }^{67}$

\footnotetext{
63 Por. R. P i e t k i e w i c z, Biblia Polonorum, t. V, s. 115, nota 28.

64 Tamże, s. 118.

65 Tamże, s. 114.

66 Tamże, s. 119.

67 Tamże, s. 119, nota 42.
} 
Czy jednak ks. Pietkiewicz ma rację, pisząc, że ks. Klawek i ks. Dąbrowski, odrzucając współpracę z „Biblią Tyniecką”, „krytycznie odnosili się do zgłaszanych w tym okresie inicjatyw przekładu Starego Testamentu z języków oryginalnych"? ${ }^{68} \mathrm{~W}$ przypadku ks. Dąbrowskiego z całą pewnością ma rację. Jak sam ks. Dąbrowski napisał już po wydaniu Biblii Tysiąclecia, w momencie gdy proszono go o współudział w projekcie, taka współpraca była możliwa tylko w przypadku Nowego Testamentu. Osobiście - pisze - w tym okresie „nie widziałem jednak w Polsce większego zespołu wykwalifikowanych specjalistów mogących sprostać takiemu zadaniu" ${ }^{69}$ Stanowisko ks. Klawka było odmienne. On ani się nie sprzeciwiał nowej próbie tłumaczenia Biblii, ani nie podjął krytyki tej inicjatywy. ${ }^{70}$ Zdawał sobie jednak sprawę, że przyszli redaktorzy, benedyktyni tynieccy, byli niezbyt kompetentni i prawdopodobnie trudno mu było potraktować ich projekt serio. Możemy przypuszczać, że nie docenił inicjatywy o. Jankowskiego i został zaskoczony zarezerwowaniem przekładu Psalmów ...dla „,benedyktynów tynieckich”, i to prawdopodobnie z Wulgaty. ${ }^{71}$ Raczej nie widział pośród nich hebraisty. Mógł tak przypuszczać, gdyż zaoferowano mu Księgę Lamentacji, innymi słowy ignorując jego zasłużoną pozycję najlepszego znawcy problematyki Psalmów w Polsce. ${ }^{72}$ Co więcej, z zachowanej korespondencji nie

68 Tamże, s. 119.

69 Por. E. D ą b row s k i, Nowy polski przekład Pisma Świętego z języków oryginalnych, Londyn 1967, s. 20; cyt. za: R. P i e t k i e w i c z, Biblia Polonorum, t. V, s. 120.

70 Gdyby ks. Klawek był przeciwny idei o. Jankowskiego, z pewnością aż czternastu jego uczniów nie wzięłoby udziału w tym przedsięwzięciu.

71 Co faktycznie miało miejsce i zostało mocno skrytykowane. Ten błąd został skorygowany w wyd. 2 Biblii Tysiąclecia. Tłumaczenie ostatecznie zweryfikowali, nawiązując do tekstu hebrajskiego, o. Jankowski i ks. prof. Lech R. Stachowiak. Przekłady dokonane przez Romana Brandstaettera i ks. Wacława Borowskiego zostały uprzednio odrzucone; por. R. P i e t k i e w i c z, Biblia Polonorum, t. V, s. $187-189$.

72 Por. np. opinię L. R. Stachowiaka: „Ogłaszane drukiem na łamach „Ruchu Biblijnego i Liturgicznego" przekłady i komentarze do wielu wybranych Psalmów (...) [są] wysoko kwalifikowanym przekładem z jęz. hebrajskiego"; L. R. S t a c h o w i a k, 
wynika, aby został zaproszony na współredaktora odpowiedzialnego za tłumaczenia Starego Testamentu. ${ }^{73}$ Uznał więc, że należy odmówić. ${ }^{74}$ Urażony, nie uczynił tego nawet na piśmie. Cztery dekady później o. Jankowski wspominał, że „Klawek poczuł się obrażony, że nie od niego zaczęliśmy. Tak mi powiedział wyraźnie, stwierdził: «wy jesteście nielojalni, bo ode mnie trzeba było zacząć»». ${ }^{75}$ Ojciec Jankowski musiał bardzo przeżyć odmowę, gdyż w innym wywiadzie wspominał, że pośród tych, którzy mu odmówili, był „i ks. Klawek, który mi ustnie wyraził żal, że nie od niego zaczęto werbunek, a przecież nie było go na tym sympozjum, kiedy to tłumnie zgłaszano akces z podaniem ksiąg". ${ }^{76}$ Faktycznie ks. Klawek wakacje zwykle spędzał w Rogoźnie, w Wielkopolsce. Jak się wydaje, o. Jankowski nie porozumiał się z ks. Klawkiem przed jego wyjazdem z Krakowa i nie przewidział ani jego nieobecności na spotkaniu biblistów, ani jego reakcji po powrocie. Cokolwiek powiedzieć, było to nieporozumienie, bo o. Jankowski powinien był uprzedzić ks. Klawka o swoim

Aleksy Klawek jako egzegeta i tłumacz Biblii, Ruch Biblijny i Liturgiczny 33/1980, s. 197

73 W zachowanych kopiach listów do ks. Klawka brak nawet śladu takiej propozycji. Natomiast w liście z 19 XII 1959 r. znajduje się sformułowanie, które musiało go mocno zaskoczyć: „Do oceny tłumaczeń od strony merytorycznej są powołani bibliści (tzw. Komitet Rewizyjny), na czele którego stoi O. Jankowski”. Biorąc pod uwagę jego pozycję jako badacza Starego Testamentu, ks. Klawek mógł poczuć się dotknięty. Nawet o. Jankowski zrozumiał w końcu stanowisko ks. Klawka. W liście do Wyd. Pallottinum z 28 V 1960 r., kiedy już było wiadomo, że ks. Klawek nie zwróci umowy o tłumaczenie Lamentacji Jeremiasza, napisał co następuje: „Natomiast trudniejszą sprawę z Ks. Prał. Klawkiem ja na razie biorę na siebie (ale też za wynik nie ręczę)". Jak się jednak wydaje, dyrekcja Pallottinum była przede wszystkim zainteresowana odzyskaniem niepodpisanej umowy. Por. list z 30 V 1960 do o. Jankowskiego: „Jeśli ks. Klawek nie chce wykonać pracy, niech odeśle umowę niepodpisaną".

74 Trzeba mieć też na uwadze, że o. Jankowski był ćwierć wieku młodszy od ks. Klawka i nie był hebraistą.

75 Wywiad R. Pietkiewicza z o. Jankowskim, datowany: Tyniec 6 XI 1999 r.; odpowiedź na pytanie nr 21 .

76 Por. list o. Jankowskiego do R. Pietkiewicza z 7 VI 2003 r.; odpowiedź na pytanie nr 8 . 
projekcie. Ksiądz Klawek był cenionym liderem krakowskich teologów, profesorem o uznanej pozycji, byłym członkiem Polskiej Akademii Umiejętności i aktualnym członkiem Komisji Filologicznej i Orientalistycznej Polskiej Akademii Nauk. Powinien był być potraktowany kurtuazyjnie, a wtedy z pewnością nie odmówiłby współdziałania i pomocy. Wydaje mi się dziwne, by o. Jankowski, przebywający w Tyńcu od 1955 r., nie znał czy też nie przyjmował do wiadomości roli pełnionej przez ks. Klawka w krakowskim środowisku naukowym.

$\mathrm{Z}$ całą pewnością była jeszcze inna przyczyna odmowy ks. Klawka. Był nim doręczony listem z 19 grudnia 1959 r. termin oddania tłumaczenia, określony na 31 maja 1960 r. Zaledwie pięć miesięcy. Będąc odpowiedzialnym człowiekiem nauki, ks. Klawek mógł uznać ofertę za mało poważną. $\mathrm{Z}$ drugiej strony trzeba przyznać, że większość biblistów dała się ponieść entuzjazmowi albo raczej wykorzystała już posiadane, ale niepublikowane tłumaczenia. ${ }^{77} \mathrm{~W}$ liście do wydawnictwa z 30 maja 1960 r. o. Jankowski stwierdził z dumą: „Nadesłano do dziś 51 ksiąg, ${ }^{78}$ z czego redakcyjnie opracowano już 37 - jak dotąd, "plan wykonany»". Był wielkim optymistą, sądząc, że całość przekładu Biblii dostarczy Pallottinum przed 1 kwietnia 1961 r. Patrząc z perspektywy pięćdziesięciu lat i wiedząc, że pierwsze korekty Biblii Tysiąclecia były gotowe dopiero w 1965 r., można podziwiać jego odwagę i entuzjazm.

Ksiądz Klawek na projekt „Biblii Tynieckiej” odpowiedział po swojemu. Pozostając w kontakcie z biblistami Wielkopolski, musiał wiedzieć, że Księgarnia św. Wojciecha i archidiecezja poznańska chciała odnowić przedwojenne, nieukończone wydanie Biblii Poznańskiej z lat 1926-1932 i tym razem przygotować nowe thumaczenie

77 Raczej to pierwsze, bo prace doskonalące przekład trwały kilka lat.

78 Trzeba powiedzieć od razu, że oferowane tłumaczenia pochodziły po większej części z gotowych, już opublikowanych lub nieopublikowanych, dysertacji lub innych prac. Kiedy ks. Klawkowi zaoferowano przekład Lamentacji, on sam opublikował z tej księgi zaledwie małą część; zob. A. K l a w e k, Słowa Boże, Ruch Biblijny i Liturgiczny 2/1949, s. 73-76; przekład Lm 3,1-33 na s. 75-76. 
z oryginalnych języków. Idea „Biblii Tynieckiej” (niedługo potem nazwanej Biblią Tysiąclecia) uprzedziła ostateczną decyzję wydawnictwa Księgarni św. Wojciecha, aby rozpocząć nowe tłumaczenie. Problem tłumaczenia był podówczas bardziej złożony. W 1959 r. ogłoszono nowe serie naukowych komentarzy z tłumaczeniami ksiąg Starego i Nowego Testamentu. Ksiądz Klawek zdał sobie sprawę, że poza „Biblią Tyniecką”, planowaną z minimalnymi przypisami i komentarzami, i poza lubelskimi naukowymi komentarzami istnieje potrzeba wydania Biblii z rozszerzonymi komentarzami dla szerokiego kręgu czytelników, dla nauczycieli religii, kaznodziejów i wykształconego laikatu. ${ }^{79}$ Jednocześnie takie tłumaczenie miało nie rezygnować ,z należytego poziomu naukowego". ${ }^{80} \mathrm{~W}$ grudniu $1960 \mathrm{r}$. ks. Klawek wysłał w tej sprawie do dyrekcji Księgarni św. Wojciecha specjalne Pro memoria. Ideę życzliwie przyjęli zarówno abp Antoni Baziak, z którym skontaktował się przedstawiciel wydawcy, jak też dyrekcja Księgarni. Propozycja tłumaczenia została przyjęta. Przyrzeczono uhonorować tę pracę, ${ }^{81} \mathrm{a}$ dwa lata potem podpisano umowę. ${ }^{82}$ Oczywiście, jak w przypadku Biblii Tysiąclecia, praca miała mieć charakter zespołowy.

Jak wspominał ks. Władysław Smereka, ,w latach 60. odbyło się u ks. Klawka w Krakowie zebranie organizacyjne, w którym wziął udział przedstawiciel Księgarni św. Wojciecha, by się zapoznać z biblistami mającymi tłumaczyć Pismo św. Na razie postanowiono pracować nad przekładem ksiąg Starego Testamentu i wydać go w dwu tomach ze względu na obszerny komentarz. Redaktorem naukowym został inicjator i wnioskodawca ks. A. Klawek, sekretarzem ks. Michał Peter, prof. Starego Testamentu w Seminarium Poznańskim, na którego barkach spoczął wielki ciężar pracy redaktorskiej”. W trakcie

79 R. Z i m n y, Całe życie z Biblia, s. 66.

${ }^{80}$ Por. M. W o l n i e w i c z, Dwa oblicza Biblii Poznańskiej, Życie i Myśl 34 (1983) nr 11-12, s. 149.

${ }_{81}$ Por. W. S m e r e k a, Biblia Poznańska (o nowym przekładzie Pisma świętego), Tygodnik Powszechny 28(1974) nr 20, w. 7.

82 Por. M. Woln i ew i c z, Dwa oblicza, s. 149-150. 
tego spotkania ustalono, że ,wstępy i komentarze, stosownie do przyjmujących się w katolickiej egzegezie tendencji, miały mieć charakter teologiczny" ${ }^{83}$ Zdecydowano, że spotkania odbywać się będą co roku, aby dyskutować metody tłumaczenia i dzielić się uzyskanymi w tym czasie rezultatami.

Spotkania zwykle odbywały się w Krakowie, ale raz zebrano się w Poznaniu, a innym razem w mieszkaniu jednego z tłumaczy w Rudzie Śląskiej. Na każdej konferencji główny redaktor przekazywał uczestnikom profesjonalne wskazówki i rady. Ksiądz Klawek od lat prenumerował holenderskie czasopismo „The Bible Translator" ${ }^{4}$ i śledził teoretyczne i metodologiczne propozycje sławnego językoznawcy Eugene Nidy (1914-2011), który rozwinął teorię dynamicznej ekwiwalencji w tłumaczeniu Biblii i który był jednym z założycieli dyscypliny zwanej translatoryką. Jak wspominał ks. Smereka: „Ks. Klawek od czterdziestu już lat zajmował się krytyką tekstu hebrajskiego, porównywał go z tekstem Septuaginty, jako onomasta współpracował z profesorami Wydziałów Humanistycznych we Lwowie i Krakowie, a także z Komisją Językoznawstwa PAN w Krakowie. $\mathrm{Z}$ tego powodu dobrze znał najnowsze techniki przekładowe i mógł swym uczniom-tłumaczom służyć pomocą, dzieląc się z nimi swoimi wiadomościami i doświadczeniem. Upominał wszystkich, by korzystali z najlepszych tradycji przekładowych i najnowszych zdobyczy z dziedziny egzegezy i nauk pokrewnych. (...) Ks. Klawek był wybitnym erudytą [nauk biblijnych] (...) i jako wspaniały organizator sprawnie całą pracą kierował". ${ }^{85}$ Warto dodać, że z początku w tłumaczenia zaangażowanych było jedynie sześciu uczniów, byłych doktorantów ks. Klawka. W kolejnych latach, z postępem prac, ta liczba powiększyła się.

83 W. S m e r e k a, Biblia Poznańska, s. 7

${ }^{84}$ Por. moje wspomnienia z wczesnych lat 60. zawarte w: Z. K a p e r a, Professor Andrzej Zaborski and the Polish Biblical Research, The Polish Journal of Biblical Research 14/2015, s. 13-14.

85 W. S m e r e k a, Biblia Poznańska, s.7. 
W latach 1962-1965 odbywał się II Sobór Watykański. Ksiądz Klawek pilnie śledził jego sesje i w wieku prawie siedemdziesięciu pięciu lat rozpoczął komentowanie jego decyzji i konstytucji. Stał się jednym z pierwszych promotorów zaleceń tego soboru na gruncie nie tylko krakowskim. Nie zaskakuje, że bibliografia jego publikacji za rok 1967 zawiera m.in. pół tuzina artykułów drukowanych w „Znaku”, progresywnym miesięczniku katolickim wydawanym w miejscu jego stałego zamieszkania. Nie tylko pisał obszerne artykuły i recenzje, tłumaczył dokumenty, jak np. konstytucję Dei Verbum, ale przede wszystkim wygłosił dla kleru i świeckich niezliczoną liczbę naukowych i popularnych wykładów na temat soboru. Uczestniczył w kolokwiach i seminariach, w spotkaniach ekumenicznych. Prowadził nawet dwa lata specjalne kursy dla krakowskich seminarzystów na temat wiary i teologii protestanckiej oraz ich gmin w Polsce. ${ }^{86}$ Poświęcenie się problematyce soborowej oczywiście odbiło się zasadniczo na regularnej pracy nad tłumaczeniem Psalmów, Pieśni nad Pieśniami i Księgi Daniela dla Biblii Poznańskiej. Wszystkie trzy przekłady pozostały ostatecznie nieukończone. ${ }^{87}$ Cokolwiek powiedzieć, jest godne ubolewania, że najbardziej kompletny, praktycznie ukończony przekład Księgi Daniela nie został włączony do Biblii Poznańskiej. ${ }^{88}$

${ }^{86}$ Por. J. W. R o sło n, Głosy biblistów polskich w sprawie doktrynalnych konsekwencji Soboru Watykańskiego II, w: J. M y ś k o w (red.), Myśl posoborowa w Polsce, Warszawa 1970, s. 306-330; zwł. s. 307-308, 309, 311, 314, 315, 317, 323, 324, 327-328.

$87 \mathrm{~W}$ papierach zebranych po śmierci ks. Klawka zidentyfikowałem przełożone obszerne fragmenty Księgi Psalmów i Pieśni nad Pieśniami; zob. Z. J. K a p e r a, Bibliografia prac księdza Aleksego Klawka, s. 334, nr 320-321.

88 Manuskrypt tłumaczenia Księgi Daniela odnalazł ks. W. Smereka tuż po śmierci ks. Klawka, ale nie został on wykorzystany do druku. Prawdopodobnie uznano to za tłumaczenie wstępne. Jednakże w porównaniu z zachowanymi częściami rękopisów tłumaczeń Pieśni nad Pieśniami i Psalmów, manuskrypt Daniela był niemal bez poprawek i wyglądał, według mnie, na rękopis przygotowany do przepisania przez maszynistkę. O jakości przekładu mogłem się przekonać w latach 70., w czasie ćwiczeń z aramejskiego w Instytucie Filologii Orientalnej UJ prowadzonych przez prof. Andrzeja Zaborskiego, jednego z ostatnich uczniów ks. Klawka; zob. Z. J. K a p e r a, Professor Andrzej Zaborski, s. 14. 
Pisząc jednak o tym okresie działalności ks. Klawka, nie sposób pominąć faktu, że tuż przed śmiercią, w 1969 r., najprawdopodobniej jako pierwszy postulował przygotowanie polskiego ekumenicznego przekładu Biblii. ${ }^{89}$

Pisząc pięć lat po śmierci ks. Klawka o początkach Biblii Poznańskiej, ks. Smereka odnotował, że ,praca nad przekładem napotykała liczne trudności. (...) Częste zmiany w Zarządzie Księgarni św. Wojciecha, a potem podeszły wiek głównego promotora dzieła miały ujemny wpływ na przebieg pracy". ${ }^{90}$ Dodatkowym kłopotem dla ks. Klawka, jako głównego redaktora, stało się żądanie Księgarni św. Wojciecha, aby przygotować także tom nowego tłumaczenia Nowego Testamentu. ${ }^{91}$ Podjął wówczas bardzo szczęśliwą decyzję zaproszenia jako współedytora ks. Mariana Wolniewicza. ${ }^{92}$ Dzięki temu dzieło

89 Por. J. W. R o s ł o n, Głosy biblistów, s. 328. Projekt ten realizuje aktualnie Towarzystwo Biblijne w Polsce. Wydano już Nowy Testament, Pentateuch, Księgi Dydaktyczne i Deuterokanoniczne (odpowiednio w latach 2001, 2014, 2011 i 2008). Kolejne tomy są w przygotowaniu.

90 W. S m e r e k a, Biblia Poznańska, s. 7.

${ }_{91}$ Według ks. M. Wolniewicza, pomysł uzupełnienia przekładu Starego Testamentu dodatkowym tomem Nowego Testamentu wyszedł od niego, ks. Petera i ks. Pytla, gdy prace tłumaczeniowe starotestamentalistów zbliżały się ku końcowi. Został on zaakceptowany przez wydawnictwo w połowie maja 1971. Redakcję tomu objął ks. M. Wolniewicz; por. M. W o $1 \mathrm{n}$ i e w i c z, Dwa oblicza, s. 150. Jednakże w liście do ks. Wolniewicza z 4 III 1967 r. ks. Klawek wyraźnie stwierdził: „.. o obecnie Wydawnictwo pragnie przystąpić także do nowego przekładu NT. Wobec tego uprzejmie zapraszam ks. Profesora - jako redaktora - do współpracy i proponuję mu przygotowanie przekładu synoptyków i Dziejów Apostolskich (z tekstu greckiego). Termin do 2 lat". Reprodukcja listu w: R. Z i m n y, Całe życie z Biblia, s. 67. Przedruk całego listu w J. P y te 1, Twarz Biblii Poznańskiej w reflektorze historii, w: M. Olcz y k, P. P o de s z w a (red.), Credidimus Caritati. Księga pamiątkowa dedykowana księżom profesorom Ryszardowi Figlowi i Tadeuszowi Haneltowi w 70. rocznice urodzin, Gniezno 2010, s. 410.

92 Ks. J. Pytel wyraził przekonanie, że kandydatura ks. M. Wolniewicza musiała mieć mocne poparcie ks. M. Petera, sekretarza Biblii Poznańskiej, jako że ks. Wolniewicz studiował na KUL-u, a wiadomo było, że ks. Klawek nie był wysokiego mniemania o poziomie naukowym studiów biblijnych na tym uniwersytecie. Opinia ks. Klawka była znana, ale nie mogę podzielić do końca poglądu ks. Pytla. Pamiętam, 
mogło zostać ukończone. Nominacja ks. Wolniewicza była z pewnością związana z faktem, że był on profesorem Nowego Testamentu w Archidiecezjalnym Seminarium Duchownym w Poznaniu, a ponadto wykładowcą greki. Musiał też być znany ks. Klawkowi jako tłumacz Dziejów Apostolskich w Biblii Tysiąclecia, osoba drukująca w „Ruchu Biblijnym i Liturgicznym”, utalentowany autor wielu artykułów w czasopismach kościelnych i tygodnikach katolickich..$^{93}$

W tym samym 1967 r. ks. Klawek podjął drugą istotną decyzję odnośnie do Biblii Poznańskiej. Ponieważ przekroczył siedemdziesiąt siedem lat, a jego zdrowie uległo znacznemu pogorszeniu, zdecydował o rezygnacji z kierowania zespołem tłumaczy, pozostając żywo zaangażowanym w bieżące życie Kościoła wprowadzającego zalecenia II Soboru Watykańskiego. Na pewno nie była to dla niego łatwa decyzja, ale szczęśliwie dyrekcja Księgarni św. Wojciecha scedowała redakcję na ks. M. Petera, który przez lata pełnił funkcję pośrednika między ks. Klawkiem a wydawnictwem.

Ksiądz M. Peter zdawał sobie sprawę z tego, że projekt Starego Testamentu nie może być ukończony wyłącznie z sześcioma uczniami ks. Klawka. Wyselekcjonował dodatkowych tłumaczy, kierując się ich osobistymi zainteresowaniem poszczególnymi księgami Biblii. Ostateczna lista tłumaczy objęła następujących księży profesorów: Jana Drozda, Witolda Gronkowskiego, Stanisława Grzybka, Józefa

że gdy jeden z członków seminarium hebrajskiego ks. Klawka z początkiem lat 60. skrytykował mocno pewien tom ks. Stanisława Łacha, lidera tzw. Lubelskiej Szkoły Biblijnej, ks. Klawek podzielił niektóre argumenty, ale sprzeciwił się ich publikacji w postaci recenzji na łamach „Ruchu Biblijnego i Liturgicznego”. Znając ks. Klawka z tych lat, jestem przekonany, że w 1967 r. nominował ks. Wolniewicza redaktorem tomu Nowego Testamentu, właściwie oceniając jego kompetencje i uzyskaną pozycję naukową; zob. J. P y t e 1, Twarz Biblii Poznańskiej, s. 410-411.

93 Ks. M. Wolniewicz (1914-2005) był wybitnym znawcą historii polskich badań biblijnych, wykładowcą Akademii Teologii Katolickiej w Warszawie i poznańskiego seminarium, ceniony jako tłumacz Ewangelii i Dziejów Apostolskich. Szkoda, że w obszernym autobiograficznym eseju jedynie wzmiankuje swój udział w przedsięwzięciu ks. Klawka, pomijając jakiekolwiek szczegóły; zob. M. W o l n i e w i c z, Autobiografia, w: F. L e n o r t (red.), Scriptura Sacra Posnanensis. Opuscula Mariano Wolniewicz Octogenario Dedicata, Poznań 2002, s. 331. 
Homerskiego, Zbigniewa Kaznowskiego, Konrada Marklowskiego, Stanisława Potockiego, Władysława Smerekę, Stanisława Stańczyka, Michała Stolarczyka, Bernarda Wodeckiego i samego Michała Petera: razem dwanaście osób. Natomiast ks. M. Wolniewicz do pracy nad przekładem Nowego Testamentu zaprosił jeszcze księży profesorów: Romana Andrzejewskiego, Janusza Czerskiego, Augustyna Jankowskiego, Franciszka Jóźwiaka, Józefa Kudasiewicza, Jana Kantego Pytla, Józefa Wiesława Rosłona, Tadeusza Szczurka, Damiana Szojdę, Edwarda Szymanka, Bernarda Wodeckiego. Konsultacji językowych udzielili tłumaczom Starego Testamentu Wanda Kieszkowska i prof. Witold Taszycki, ${ }^{94}$ a tłumaczom Nowego Testamentu Irena Kwilecka i Elżbieta Kędzielska. ${ }^{95}$

Pierwszy tom nowego tłumaczenia Starego Testamentu ukazał się w 1974 r. Liczył niemal tysiąc stron - od Księgi Rodzaju po Drugą Księgę Machabejską. ${ }^{96}$ Tom drugi ukazał się w 1975 r. i na ponad tysiącu trzystu stronach znalazły się pozostałe księgi Starego Testamentu. ${ }^{97}$ Rok później ukazał się tom trzeci zawierający na niemal sześciuset stronach całość Nowego Testamentu. ${ }^{98} \mathrm{~W}$ porównaniu z pierwszym wydaniem Biblii Tysiąclecia z 1965 r., obejmującej całość Biblii na tysiącu pięciuset stronach, dokonano wielkiego postępu w komentowaniu Pisma Świętego dla każdego czytelnika. Dzięki komentarzom Biblia Poznańska była dwa razy obszerniejsza od Biblii Tysiąclecia. Ksiądz M. Peter w audycji dla Radia Watykańskiego tak wyjaśnił różnice między Biblią Tysiąclecia a Biblią Poznańską: „Biblia Tysiąclecia ograniczyła się świadomie do umieszczenia pod tekstem jedynie krótkich notek objaśniających. Choć są one najczęściej

94 Witold Taszycki (1898-1979), kolega ks. Klawka, wybitny historyk języka polskiego, onomastyk i dialektolog.

95 Por. M. Woln i ew i c z, Dwa oblicza, s. 150.

96 Stary Testament. Tom pierwszy, Pismo Święte Starego i Nowego Testamentu w przekładzie z języków oryginalnych ze wstępami i komentarzami. Opracował zespół pod redakcją ks. Michała P e t e r a (Stary Testament), ks. Mariana W o 1 n i e w i c z a (Nowy Testament), Poznań 1973.

${ }_{97}$ Stary Testament. Tom drugi, Poznań 1975.

98 Nowy Testament, Poznań 1975. 
jasne i trafne, to jednak z natury rzeczy obejmują tylko część problemów nasuwających się przy lekturze. Nowy przekład poznański posiada stosunkowo obszerny Komentarz towarzyszący u dołu Tekstowi. Jest on nastawiony głównie na teologię każdej Księgi, jako najważniejsze jej złoże treściowe. Uwagi geograficzno-historyczne czy archeologiczne, bo przecież nie brak i takich, są zwięźle ujęte. Czytelnik duchowny, katecheta czy homileta, jak i Czytelnik świecki, szukający treści Biblii, znajdą ją łatwo, nie gubiąc się w mniej istotnych szczegółach, interesujących tylko wąskie grono specjalistów: historyków starożytności, językoznawców, egzegetów". 99

Biblia Poznańska miała w latach 1975-2014 oficjalnie cztery wydania: (1) 1973-1975 100 , (2) 1982-1987, (3) 1991-1994 i (4) w 1999 r. W kolejnych latach były liczne reprinty. ${ }^{101}$ Ten przekład pozostaje nadal drugą, po Biblii Tysiąclecia pozycją w ogólnej dystrybucji tłumaczeń Biblii w Polsce. Jest godne ubolewania, że w ciągu czterdziestu lat po tej publikacji tak rzadko profesjonalnie ją recenzowano czy omawiano, ${ }^{102}$ w porównaniu z ocenami Biblii Tysiąclecia. Była też zaledwie jedna recenzja w języku obcym. ${ }^{103}$ Tylko o. Józef W. Rosłon i ks. Janusz Frankowski opublikowali uwagi krytyczne, i to tylko odnośnie do pierwszych dwu tomów poświęconych Staremu Testamentowi. Ojciec Rosłon podkreślił, że tłumacze przyjęli następujące założenia: 1) Zdecydowali zachować „daleko idącą wierność oryginałowi”. Postawili to wyżej niż piękno języka polskiego. Przekład miał być wydaniem źródłowym. Jednakże ,trudności techniczne nie pozwoliły wydrukować krytyki tekstu. Niektóre jej spostrzeżenia dano w przypisach

99 Por. (M), Nowy polski przekład Pisma świętego, Przewodnik Katolicki 14/1974, s. 8. Artykuł ten zawiera podsumowanie wywiadu przeprowadzonego przez o. Tadeusza Rostworowskiego z prof. Michałem Peterem 27 VI 1973 r.

${ }^{100}$ Według ks. Wolniewicza, rzeczywiste lata dystrybucji poszczególnych tomów pierwszego wydania to 1974, 1975 i 1976; por. M. Woln i e w i c z, Dwa oblicza, s. 151.

${ }^{101}$ Por. P. O s t a ń s k i, Bibliografia biblistyki polskiej, t. V: 2010-2013/2014, Poznań 2015, s. 136-139, nr 1019.

${ }^{102}$ Zauważył to już M. W o $1 \mathrm{n}$ i e w i c z, Dwa oblicza, s. 151, 153, nota 36.

${ }^{103}$ Była to recenzja J. S c h a r b e r t a w Biblische Zeitschrift 20/1976, s. 149-150. 
(komentarzu) z odsyłaczem „K”'. 2) Zostawiono tylko piękniejsze i bardziej zrozumiałe semityzmy. Inne przełożono w duchu języka polskiego. 3) Zadbano „o poprawne stylistyczne brzmienie zdań”. 4) Zezwolono na niezbędne retusze literackie, dając czasem dosłowny przekład w komentarzu. 5) Poza powszechnie przyjętymi, imiona własne zostały oddane zgodnie z brzmieniem i pisownią hebrajską czy grecką. 6) Starano się oddać po polsku grę słów hebrajskich. 7) Słowa dodane umieszczono w nawiasach kwadratowych, glosy tekstowe w nawiasach okrągłych; ograniczono cudzysłowy. 8) Poetyckie fragmenty tekstu oddano układem wierszowym.

Natomiast co do komentarza, to tłumacze kierowali się następującymi zasadami: 1) Miał być krótszy od tekstu, bo jego rola jest pomocnicza. 2) Należy kłaść nacisk na objaśnienia natury teologicznej. 3) Noty bibliograficzne dawać tylko w absolutnie niezbędnych przypadkach. 4) Dla użytku homiletów cytować teksty paralelne, ewentualnie dodawać też uwagi liturgiczne. Całościowa ocena Biblii Poznańskiej była dla o. Rosłona wyższa niż Biblii Tysiąclecia. Jej walory pastoralne i liturgiczne, a nawet graficzne, zostały ocenione wysoko. Niektóre rozwiązania związane z krytyką tekstu rekomendował nawet do wykorzystania w innych przekładach. Sumując, o. Rosłon pisał: „Ogólnie biorąc, trzeba pochwalić i wydawnictwo, i redakcję, i autorów za staranność, dbałość, sumienność, estetykę, owo «nachylenie» duszpasterskie i liturgiczne, czyniące z tego dzieła dobrze zastawiony stół - szulhan aruk dla księży i dla ludu Bożego". Jedyne zastrzeżenie, jakiemu dał wyraz o. Rosłon, to zbyt obszerne komentarze (w porównaniu do tekstu thumaczonego) w tomie drugim Starego Testamentu i pominięcie w komentarzach wyników badań nad literaturą ugarycką i fenicką. ${ }^{104}$

Opinia ks. J. Frankowskiego, biblisty literaturoznawcy, była krótka, ale dobitna: „Trzytomowa Biblia Poznańska jest w poszczególnych księgach bardzo nierówna. Są księgi dobrze przetłumaczone, np. Izajasz, Jeremiasz, Ewangelie. Pięcioksiąg jest przetłumaczony

104 Podsumowanie i cytaty z recenzji J. W. R o s $ł$ o n, Collectanea Theologica 46 (1976) nr 1, s. 235-237. 
pedantycznie. Listy do Koryntian są przeinterpretowane. Cały ten przekład zresztą zdradza pewną tendencję właśnie do pedantyczności i przeinterpretowania". ${ }^{105} \mathrm{Z}$ drugiej strony Jan Turnau, osoba świecka i znany dziennikarz katolicki, był zbudowany nowymi jakościami przekładu Biblii Poznańskiej. Były to według niego obfite komentarze do tekstu, czasem dłuższe niż sam tekst, śmiałość przekładu i uwspółcześnienie edycji przez nowoczesny układ graficzny tekstu. „Podobnie jak w «normalnych» książkach, wypowiedzi bohaterów dzieła są tu oddzielone myślnikiem i akapitem od reszty narracji. Urozmaicenia te czynią tekst bardziej przejrzystym, czytelnym, a przede wszystkim - bardziej zwyczajnym. Sugerują, że jest to książka całkiem zwyczajna, ludzka, choć zarazem całkiem niezwykła, Boża...”106 Jan Turnau nie szczędził pochwał, znajdując wiele nowych rozwiązań i propozycji w Biblii Poznańskiej, wiele z nich akceptując, inne jednak krytykując. Nie wszystkie wstępy i komentarze podobały mu się, ale życzył wydawcom nowych wydań, co zresztą miało miejsce w kolejnych dekadach. ${ }^{107}$

Ponad ćwierć wieku po pierwszym wydaniu Biblii Poznańskiej dr hab. Marek Piela z Uniwersytetu Jagiellońskiego, jako doktorant prof. A. Zaborskiego, w swej ciągle mało znanej pracy na temat grzechu dosłowności w tłumaczeniach Starego Testamentu, wziął po części pod lupę także i to tłumaczenie. Potraktował je jako przekład nie zakładający u czytelnika znajomości oryginału, choć nieprzeznaczony do powszechnego użytku. ${ }^{108} \mathrm{~W}$ przeciwieństwie do cytowanych wyżej recenzentów, przedstawił rzeczową, choć pozytywną, krytykę, wskazując (podobnie jak w wielu innych polskich tłumaczeniach) na grzech dosłowności przy wielu okazjach. ${ }^{109}$ Jednakże w porównaniu $\mathrm{z}$ innymi ostatnio wydanymi tłumaczeniami Biblię Poznańską zaliczył do grupy przekładów niedosłownych. Choć oczywiście, jego

\footnotetext{
105 J. F r a n k o w s k i, Wokót psalmów i kantyków, Więź 9/1976, s. 13.

106 Tu ri a n [J. Tu r n a u], Mamy nowa Biblię, tamże, s. 26.

107 Tamże, s. 31.

${ }_{108}$ Por. M. P i e la, Grzech dosłowności, s. 32.

109 Np. zachowując liczne powtórzenia w genealogiach biblijnych; tamże, s. 19.
} 
zdaniem, „dobry przekład oprócz niedosłowności musi spełniać inne jeszcze warunki". ${ }^{110}$

Jest godne ubolewania, że w czasie czterech krakowskich konferencji cyklu tłumaczeń z języków orientalnych ani w trakcie niedawnych konferencji na temat tłumaczeń Biblii na język polski Biblia Poznańska nie znalazła się w kręgu zainteresowań prelegentów i w rezultacie do dziś tak naprawdę nad nią nie dyskutowano. Należy się jej więcej uwagi, szczególnie że nie żyją niemal wszyscy jej tłumacze, zaś otwarta i dogłębna krytyka pomogłaby ją poprawić. W mojej prywatnej opinii jest to pomnik lat 70., który oparł się biegowi czasu, a jego poprawienie w znacznym stopniu pomogłoby zachować przekład jeszcze na wiele dekad.

Założenia przyjęte przez ks. prof. Aleksego Klawka znakomicie wpisały się w posoborowy dezyderat zaoferowania laikom nowego tłumaczenia Biblii z języków oryginalnych. Projekt został doskonale ukierunkowany i ukończony przez dwu jego współpracowników, ks. Michała Petera i ks. Mariana Wolniewicza. Jego pośmiertnym triumfem była ocena dokonana przez polskich biblistów w $1999 \mathrm{r}$. Biblia Poznańska w dwudziestopunktowym rankingu uzyskała najwięcej, bo 16,63 punktu, pokonując znacząco nie tylko tłumaczenia z KUL-owskiej serii komentarzy Starego i Nowego Testamentu (11,97 punktów), ale nawet Biblię Tysiąclecia $(11,69) .{ }^{111}$ Tę wysoką pozycję Biblia Poznańska uzyskała za jasność i staranność. A brano pod uwagę następujące kryteria: 1) wierność, przy czym wyżej oceniano przekłady dosłowniejsze; 2) staranność (tzn. jednolitość metody, brak pomyłek itd.); 3) piękno języka; 4) jasność (przystępność przekładu dla współczesnego czytelnika); 5) użyteczność (przydatność w duszpasterstwie, nauczaniu religii, jakość komentarzy). W tych kategoriach Biblia Poznańska uzyskała odpowiednio 2,40 - 2,61 - 2,47-2,62

110 Tamże, s. 288.

111 Według przekazu ks. J. K. Pytla, kard. Stefan Wyszyński miał przed śmiercią z uznaniem wypowiedzieć się o Biblii Poznańskiej, ocenić ją jako bardzo dobrą. Zdanie to podzielił także o. A. Jankowski; por. J. K. P y t e 1, Twarz Biblii Poznańskiej, s. 412. 
- 2,53 punktów. Byłoby celowe, by po kolejnych piętnastu latach powtórzyć ankietę Katolickiej Agencji Informacyjnej i zobaczyć, jak dziś wyglądałaby ta klasyfikacja. Jest jednak bardzo prawdopodobne, że nawet dziś, mimo upływu czterdziestu lat od jej narodzin, Biblia Poznańska zachowała swoją pozycję. Mogłyby na to wskazywać kolejne jej dodruki i powszechne uznanie w środowisku naukowym, nie tylko pośród biblistów, ale historyków starożytnych, palestynologów i archeologów czy znawców antyku. ${ }^{112}$

$$
* * *
$$

Autor pragnie wyrazić wdzięczność ks. dr hab. Rajmundowi Pietkiewiczowi za udostępnienie ze swojego archiwum dotyczącego Biblii Tysiąclecia kopii listów Wydawnictwa Pallottinum do ks. prof. Aleksego Klawka i niektórych listów o. Augustyna Jankowskiego do jego Wydawcy, jak też tekstów swoich wywiadów z redaktorem Biblii Tysiąclecia. Dzięki znajomości ich treści mogłem wyrazić swoją opinię na temat początków Biblii Poznańskiej. Księdzu prof. dr hab. Janowi K. Pytlowi jestem zobowiązany za życzliwe odpowiedzi na pytania związane z Biblia Poznańską, a ks. dr. hab. Piotrowi Ostańskiemu za ułatwienie dostępu do niektórych recenzji i informacji o tej publikacji.

Zdzistaw J. KAPERA

Słowa kluczowe: Biblia Poznańska, Biblia Tysiąclecia, konferencje biblistów polskich, tłumaczenia Biblii, Augustyn Jankowski, Aleksy Klawek, Michał Peter, Marian Wolniewicz

112 Należy wyrazić nadzieję, że przygotowywana pod kierunkiem ks. dr. hab. R. Pietkiewicza praca doktorska na temat historii Biblii Poznańskiej przyniesie nowe ustalenia. 
Keywords: The Poznań Bible, The Millennium Bible, symposia of the Polish biblical scholars, translations of the Bible into Polish, Augustyn Jankowski, Aleksy Klawek, Michał Peter, Marian Wolniewicz

\section{Rev. Professor Aleksy Klawek and the Poznań Bible Summary}

The Rev. Prof. Aleksy Klawek (1890-1969) was a great Polish Old Testament scholar who can certainly also be called a great Hebrew scholar. His dream was to create a modern translation of the Bible directly from Hebrew, Aramaic and Greek, and Poland had long been in need of one, as Wujek's translation of 1597 was outdated and not easy to understand. But it took Klawek years before he decided to present his first fragmentary translations; this happened in the late 1930s and 1940s. It is not clear why Klawek did not join the team of translators of the so-called "Tyniec Bible", now known as the "Millennium Bible", in 1959, but being aware of the weakness of Father Augustyn Jankowski's translating team, Klawek formed his own team before the publication of the "Millennium Bible" composed mostly of his former Ph.D. students. In the end, we did not receive a modern translation of the Bible from Klawek's hands as he died in 1969. His idea was put into practice under the editorship of his pupil Michał Peter and Marian Wolniewicz. As Klawek's translations of Psalms, Song of Songs and Daniel remained unfinished, all that the editors could do was to gratefully acknowledge Klawek's initiative. The new "Poznan Bible", which appeared in the years 1974-1976, is much prized for its quality (clarity and accuracy) and its extensive commentaries. 